\title{
Multilayer polymeric films for controlled release of ceftriaxone sodium
}

\section{Ceftriaxone sodyumun kontrolliu salımı için çok katmanlı polimerik filmler}

\author{
Aysel KIZILTAY ${ }^{1}$, Zeynep GÜNDOĞAN² ${ }^{2}$, İrem EREL-GÖKTEPE², Nesrin HASIRCI
}

\section{ABSTRACT}

Objective: The objective of this study was to prepare a controlled release system, which could be used in medical applications in order to treat infections at the host region.

Methods: Microlayer films were prepared via solvent casting method. Films with 3-layers were prepared by using chitosan $(\mathrm{CHI})$, gelatin (GEL) and alginate (ALG) in the form of $\mathrm{CHI} / \mathrm{ALG} / \mathrm{CHI}$ and CHI-GEL /ALG/CHI-GEL with or without ceftriaxone sodium (CS) which is loaded in the middle ALG layer. All films were crosslinked by exposing them to glutaraldehyde (GA) vapor for different ( $2 \mathrm{~h}, 10 \mathrm{~h}$ or $24 \mathrm{~h}$ ) durations. Mechanical properties of the films and release kinetics of CS at three different $\mathrm{pH}$ conditions ( $\mathrm{pH} 5.5,7.4$, and 10.0) were investigated. The antibacterial efficiency of the released CS against Escherichia coli was examined via agar spot test.

Results: The results indicated that the presence of GEL in the upper and lower layers of the 3-layer construct prevented fragility and increased the mechanical strength of the films, whereas the presence of CS in the middle layer caused decrease in the mechanical properties. Crosslinking with GA did not demonstrate a significant effect on the release profile of $\mathrm{CS}$, but

\section{ÖZET}

Amaç: Bu çalıșmanın amacı konakçı bölgede enfeksiyonu tedavi etmek amaciyla medikal alanda kullanılabilecek kontrollü salım sistemi hazırlamaktır.

Yöntem: Mikro katmanlı filmler çözelti döküm metodu ile hazırlanmıștır. Üç katmanlı filmler kitosan $(\mathrm{CHI})$, jelatin (GEL) ve aljinat (ALG) kullanılarak aljinat tabakasına ceftriaxone sodyum (CS) yüklenmiș, ayrıca kontrol grubu için ilaç yüklenmemiş olarak hazırlanmış ve sirasiyla $\mathrm{CHI} / \mathrm{ALG} / \mathrm{CHI}$ ve CHI-GEL/ALG-CS/CHI-GEL olarak kodlandırılmıștır. Bütün filmler glutaraldehit (GA) buharına farklı süre boyunca $(2 \mathrm{~h}, 10 \mathrm{~h}$ veya 24 h) tabi tutularak çapraz bağlanmıștır. Filmlerin mekanik özellikleri ve CS'nin filmlerden salım kinetikleri üç farklı $\mathrm{pH}$ șartlarında (pH 5,5, 7,4, ve 10,0) incelenmiștir. Salınan CS'nin Escherichia coli'ye karşı antibakteriyel etkinliği agar spot yöntemiyle test edilmiștir.

Bulgular: Sonuçlar üç-katmanlı film yapılarının üst ve alt katmanında GEL varlığının filmlerin kırılganlığı önlediğini ve mekanik dayanımını arttırdığını, ancak orta katmanda CS varlığının mekanik özellikleri düşürdüğünü göstermiștir. Filmlerin GA ile çapraz bağlanması CS'nin salımında anlamlı bir etki göstermemiștir, ancak kitosanın aljinat ve CS ile etkileșiminden dolayı ilaç

'Middle East Technical University, Central Laboratory, Ankara

${ }^{2}$ Middle East Technical University, Department of Chemistry, Ankara

İletişim / Corresponding Author : Aysel KIZILTAY

Üniversiteler Mh., Dumlupınar Blv. No: 1, Çankaya 06800 Ankara - Türkiye

Tel : +905426676919 E-posta/E-mail : kiziltay@metu.edu.tr

Geliş Tarihi/Received : 17.01.2019

Kabul Tarihi/Accepted : 30.07.2019

DOI ID : 10.5505/TurkHijyen.2019.85579

Kızıltay A, Gündogan Z, Erel-Göktepe I, Hasırcı N. Multilayer polymeric films for controlled release of ceftriaxone sodium.

Turk Hij Den Biyol Derg, 2019; 76(3): 303-312 
due the interaction of chitosan with alginate and CS, the drug release was delayed. Antibacterial tests which were carried out by using the released media of drug loaded films displayed inhibition zone in agar spot tests against $E$. coli.

Conclusion: It was concluded that multilayered films prepared by solvent casting can be good candidates as drug carrier devices in medical applications.

Key Words: Gelatin, chitosan, alginate, ceftriaxone sodium, polymeric film, drug release salım hızında azalma olmuștur. İlaç yüklü filmlerden salınan ilaç çözeltisinin kullanılmasıyla $E$. coli ile yapılan antibakteriyel deneyler, agar spor testlerinde inhibisyon zonu oluștuğunu göstermiștir.

Sonuç: Çözücü döküm metodu ile hazırlanan çok katmanlı filmlerin medikal uygulamalarda ilaç taşıyıcı sistem olarak kullanım için iyi bir aday olduğu düșünülmektedir.

Anahtar Kelimeler: Jelatin, kitosan, aljinat, ceftriaxone sodyum, polimerik film, ilaç salımı

\section{INTRODUCTION}

Drug delivery systems are used to improve therapeutic effects of the drugs by minimizing undesirable side-effects and by releasing the required amounts at the desired regions with a controlled mechanism. Nano-size systems are mostly produced as nanoparticles, micelles, liposomes, dendrimers etc. However, nano-particles have short half-life in the circulation due to uptake into macrophages which would decrease the amount of the drug delivered (1). Other release alternatives are loading of the drugs directly to the biodegradable membranes or hydrogel matrices which allow local delivery of the active agent (2-6). Biologically derived polymers such as chitosan, alginate, hyaluronic acid, collagen and gelatin have been intensely investigated in the biomedical field, including tissue engineering and drug delivery applications, due to their remarkable properties (7-9). In the biomedical field, although the use of synthetic polymers is easier, natural polymers are preferable due to their relative biocompatibility and biodegradability $(10,11)$. Chitosan, which is a cationic polysaccharide with the antibacterial property (12), has been widely studied as a potential biomedical material and has blends with synthetic and/or other natural polymers (13-16). For example, Sionkowska et al. prepared composite matrices by blending chitosan with collagen to study gentamicin sulfate release (17).
Alginate is an elastic, irreversible hydrocolloid and a pH sensitive anionic polysaccharide, forms gel at low $\mathrm{pH}$ and stable in acidic conditions but swells and dissolves in alkaline $\mathrm{pH}$ (18). The major disadvantage of alginate based delivery systems is rapid release of the loaded molecules. Therefore, it is modified either by crosslinking with multivalent cations or used in combination with other polymers such as chitosan (19).

In the last decades, chitosan and alginate become attractive natural polymers for preparation of polyelectrolyte complexes and layer-by-layer (LbL) matrix applications. These natural polysaccharides are suitable for chemical modifications and are highly available; therefore, they are preferable polymers to be used for the design of drug delivery systems (20-22). Use of polymeric hybrid membranes loaded with active agents has been reported for various purposes. A unique advantage to the use of $\mathrm{LbL}$ assembly is its ability to incorporate drugs in high concentrations within a multilayer thin film (23). Silva et al. developed drug-loaded ophthalmic lenses using layered deposition of chitosan and alginate, and the coated lenses demonstrated sustained release of antiinflammatory drug up to 1 week (24). Stabilization of collagenous materials is often achieved by glutaraldehyde crosslinking due to its high efficiency 
(25).

In this study, films with two different designs were produced as 3-layered structures in micron size by using chitosan, alginate and gelatin to study the release of ceftriaxone sodium (CS). The effect of different crosslinking time using glutaraldhyde vapor on drug release and mechanical properties of the films was investigated. The release kinetics of CS at different $\mathrm{pH}$ conditions, and the antibacterial efficacy of the released drug towards Escherichia coli were examined. To the best of our knowledge, there is no study about multilayered systems including three different polymers as described here.

\section{MATERIAL and METHOD}

\section{Materials}

Chitosan (low viscous, 75 - 85\% deacetylated) was obtained from Fluka (Osaka, Japan); gelatin powder was obtained from Scharlau (Barcelona, Spain); alginic acid (sodium salt from brown algae), ethanol (pure, free from acetone) and glutaraldehyde (25\% aqueous solution) were obtained from Sigma-Aldrich (St. Louis, USA). Ceftriaxone sodium was obtained from Nobel Kimya (Istanbul, Turkey).

\section{Preparation of multilayered membranes}

Two different types of films were prepared as 3-layered structures by using chitosan ( $\mathrm{CHI})$, alginate (ALG) and gelatin (GEL) as polymers by casting method (26). In the first type of films, ALG was the middle layer that placed in between $\mathrm{CH}$ layers, and in the second type of films, the first and the third layers were blends of $\mathrm{CHI}$ and GEL, and the middle layer was again ALG. An antibiotic, ceftriaxone sodium (CS) was added in the middle ALG layers in both designs. The first types of the films were coded as $\mathrm{CHI} / \mathrm{ALG} / \mathrm{CHI}$ and the second types of films were coded as CHI-GEL/ALG/CHI-GEL.

\section{Preparation of $\mathrm{CHI} / \mathrm{ALG} / \mathrm{CHI}$ and $\mathrm{CHI} / \mathrm{ALG}-\mathrm{CS} /$ $\mathrm{CHI}$ films}

$\mathrm{CHI}$ solution $(10 \mathrm{~mL}, 1 \% \mathrm{w} / \mathrm{v}$ in $1 \% \mathrm{v} / \mathrm{v}$ acetic acid) was homogenized in a sonicator for 10 minutes and was put into petri dishes $(r=4.5 \mathrm{~cm})$. The solution was dried in oven at $37^{\circ} \mathrm{C}$. ALG solution $(10 \mathrm{~mL}, 1 \% \mathrm{w} / \mathrm{v})$ was prepared in distilled water, slowly and carefully added on $\mathrm{CHI}$ layer and let to dry. The third layer was obtained by adding $\mathrm{CHI}$ solution on top of the dried ALG layer. For the films which contain antibiotic (CS), $\sim 30 \mathrm{mg}$ of drug was added in ALG solution, so that there would be $0.5 \mathrm{mg} \mathrm{CS}$ per $\mathrm{cm} 2$ of the membrane. The prepared films were allowed to dry for 2 days at room temperature. Films were crosslinked by exposing them to GA vapor (by using 25\% GA solution) for $2 \mathrm{~h}$, $10 \mathrm{~h}$ and $24 \mathrm{~h}$, where the uncrosslinked ones were used as controls.

\section{Preparation of CHI-GEL/ALG/ CHI-GEL and CHI-GEL/ALG-CS/ CHI-GEL blend films}

$\mathrm{CHI}$ solution $(1 \% \mathrm{w} / \mathrm{v})$ was prepared in aqueous acetic acid solution (1\% v/v) and GEL solution (1\% $\mathrm{w} / \mathrm{v}$ ) was prepared in distilled water (around $50^{\circ} \mathrm{C}$ ).

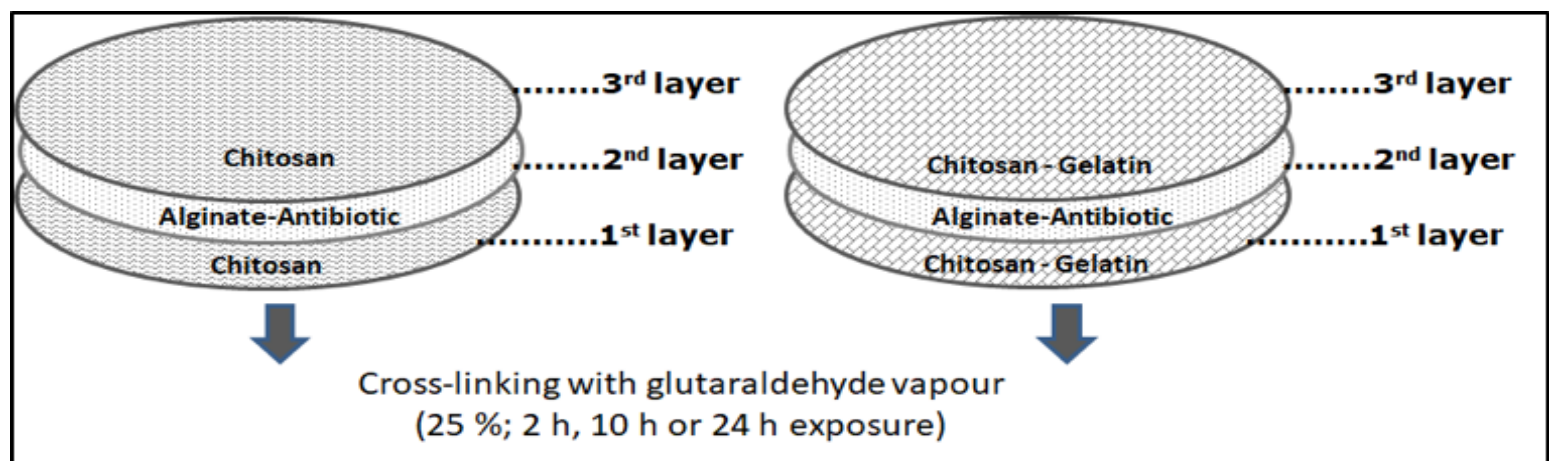

Figure 1. Schematic presentation of the 3-layer films 
Then, equal amounts of these solutions were mixed, homogenized in a sonicator for 10 minutes, $10 \mathrm{~mL}$ of it was put into petri dishes as the first layer and then allowed to dry. As the second layer, $10 \mathrm{~mL}$ of ALG solution $(1 \% \mathrm{w} / \mathrm{v})$ with or without CS was added as described previously. After that, $10 \mathrm{~mL}$ of the prepared CHI-GEL solution was added on the dried films as the third layer. Some films were crosslinked by exposing them to GA vapor (by using $25 \%$ GA solution) for $2 \mathrm{~h}, 10$ $\mathrm{h}$ and $24 \mathrm{~h}$. The schematic presentations of the 3-layer films are given in Figure 1.

\section{Mechanical analysis of the membranes}

The mechanical properties of the films were studied according to the method of Endogan et al. by using a Mechanical Tester (Lloyd LRX 5K), controlled by a computer running program (WindapR) (14). For tensile testing, the films were cut in rectangular form (width $=10.0 \mathrm{~mm}$, length $=40.0 \mathrm{~mm}$ ) and attached to the holders of the instrument with a Gauge length of $10 \mathrm{~mm}$. The tensile strength (TS) value was obtained from equation $\rho=F / A$, where $\rho$ is the maximum tensile strength $(\mathrm{MPa}), \mathrm{F}$ is the maximum load applied $(\mathrm{N})$ before break, and $\mathrm{A}$ is the initial area $(\mathrm{m} 2)$ of the films. The load deformation values were converted to stress-strain curve, where stress is the load applied per unit area and strain is the deformation per unit length. Slope of straight line (elastic region of the stress-strain curve) is accepted as the Young's modulus (YM) of the specimen. Percent elongation (EAB\%) of the films was measured by dividing the maximum extended values to initial gauge length. Average of at least five experimental data was taken for each sample.

\section{Drug release from membranes}

Release of CS from the crosslinked and uncrosslinked films were studied using PBS buffer solutions prepared at different $\mathrm{pH}$ values $(\mathrm{pH} 5.5, \mathrm{pH} 7.4$ and $\mathrm{pH}$ 10.0) (5). The films were cut in rectangular shape $(2 \mathrm{~cm} x$ $1 \mathrm{~cm}$ ), placed into $5 \mathrm{~mL}$ PBS solution and kept at 37 $\mathrm{OC}$ in a temperature controlled water bath shaker. At certain time points, the solutions were removed and absorbance values were obtained at $300 \mathrm{~nm}$. The complete release medium was changed with fresh PBS after each measurement. Films that were not drug loaded were also kept in the similar buffer conditions and their solutions were used as control blanks for UV absorption studies. Meanwhile, releasedmedia of $\mathrm{CHI}$ GEL/ALG-CS/CHI-GEL films, which were crosslinked by exposing to GA vapor for $2 \mathrm{~h}$ or $10 \mathrm{~h}$, were taken and stored for further antibacterial tests.

\section{Antibacterial test}

Antibacterial activity of the released CS was studied against E. coli (ATCC 25922, Gram-negative bacterial strain) by using agar spot test as described in a previous study (27). For this purpose, E. coli suspension was spread on agar plates with cotton swabs. Meanwhile, the collected released media of the samples was filtered and $100 \mu \mathrm{L}$ were added into plates. Plates were then incubated at $37{ }^{\circ} \mathrm{C}$ for $24 \mathrm{~h}$. The inhibitory activity was measured based on the clear zone. Solutions gathered from the drug free films ( $2 \mathrm{~h}$ and $10 \mathrm{~h}$ GA crosslinked CHI-GEL/ALG/CHI-GEL) were used as negative control groups and $30 \%(\mathrm{w} / \mathrm{v})$ aqueous CS solution was used as positive control.

\section{RESULTS}

\section{Mechanical properties of multilayer membranes}

Tensile strength (TS) of a material is defined as the maximum force applied per unit area and usually given with unit of Pascal (Pa), Mega-Pascal (MPa) or GigaPascal (GPa). Young's modulus (YM) (tensile modulus or elastic modulus) is the measure of the stiffness of an elastomeric material and measured as the ratio of the applied stress to the deformation at the elastic region of the material. Elongation at break $(E A B, \%)$ is defined as the percent deformation (strain) at fracture. In general, materials with high $Y M$ usually show low $E A B$ (28).

For drug unloaded and CS loaded films, TS and EAB values of uncrosslinked $\mathrm{CHI} / \mathrm{ALG} / \mathrm{CHI}$ and $\mathrm{CHI} / \mathrm{ALG}$ $\mathrm{CS} / \mathrm{CHI}$ samples were found as $88.60 \mathrm{MPa}$ and $11.33 \%$ and as $96.40 \mathrm{MPa}$ and $11.90 \%$, respectively (Table 1 ). Meanwhile, the crosslinked forms of these films were highly fragile and did not endure the applied load. 
Therefore, mechanical analysis tests could not been carried out for the crosslinked films.

In order to prevent fragility of the films, gelatin was blended with chitosan and the second group films
(CHI-GEL/ALG/CHI-GEL and CHI-GEL/ALG-CS/CHI-GEL) were prepared. Thus, the strengths of the films were enhanced. TS, YM and EAB\% values obtained are given in Table 1 and Figure 2a-c). A decrease was observed

Table 1. Mechanical test results of prepared films

\begin{tabular}{|c|c|c|c|}
\hline Sample & TS $(\mathrm{MPa})$ & YM (GPa) & Strain \% \\
\hline $\mathrm{CHI} / \mathrm{ALG} / \mathrm{CHI}$ & $88.60 \pm 7.86$ & $1.30 \pm 0.01$ & $11.33 \pm 5.09$ \\
\hline $\mathrm{CHI} / \mathrm{ALG}-\mathrm{CS} / \mathrm{CHI}$ & $96.40 \pm 3.52$ & $1.27 \pm 0.05$ & $11.90 \pm 1.61$ \\
\hline CHI-GEL/ALG-CS/CHI-GEL & $60.55 \pm 6.86$ & $1.54 \pm 0.13$ & $4.20 \pm 0.68$ \\
\hline CHI-GEL/ALG/CHI-GEL & $104.52 \pm 5.90$ & $1.58 \pm 0.41$ & $16.15 \pm 6.95$ \\
\hline $\begin{array}{l}\text { CHI-GEL/ALG-CS/CHI-GEL, } \\
2 \text { h GA treatment }\end{array}$ & $81.21 \pm 19.70$ & $1.78 \pm 0.45$ & $7.98 \pm 3.53$ \\
\hline $\begin{array}{l}\text { CHI-GEL/ALG/CHI-GEL, } \\
2 \text { h GA treatment }\end{array}$ & $129.43 \pm 41.69$ & $1.93 \pm 0.44$ & $8.34 \pm 2.94$ \\
\hline $\begin{array}{l}\text { CHI-GEL/ALG-CS/CHI-GEL, } \\
10 \text { h GA treatment }\end{array}$ & $39.56 \pm 23.61$ & $1.19 \pm 0.16$ & $8.22 \pm 2.03$ \\
\hline $\begin{array}{l}\text { CHI-GEL/ ALG/CHI-GEL, } \\
10 \text { h GA treatment }\end{array}$ & $69.42 \pm 5.28$ & $1.28 \pm 0.12$ & $11.59 \pm 2.08$ \\
\hline $\begin{array}{l}\text { CHI-GEL/ALG-CS/CHI-GEL, } \\
24 \text { h GA treatment }\end{array}$ & $72.68 \pm 4.75$ & $1.83 \pm 0.22$ & $4.93 \pm 0.67$ \\
\hline $\begin{array}{l}\text { CHI-GEL/ALG/CHI-GEL, } \\
24 \text { h GA treatment }\end{array}$ & $97.60 \pm 7.63$ & $1.35 \pm 0.05$ & $20.03 \pm 7.77$ \\
\hline
\end{tabular}
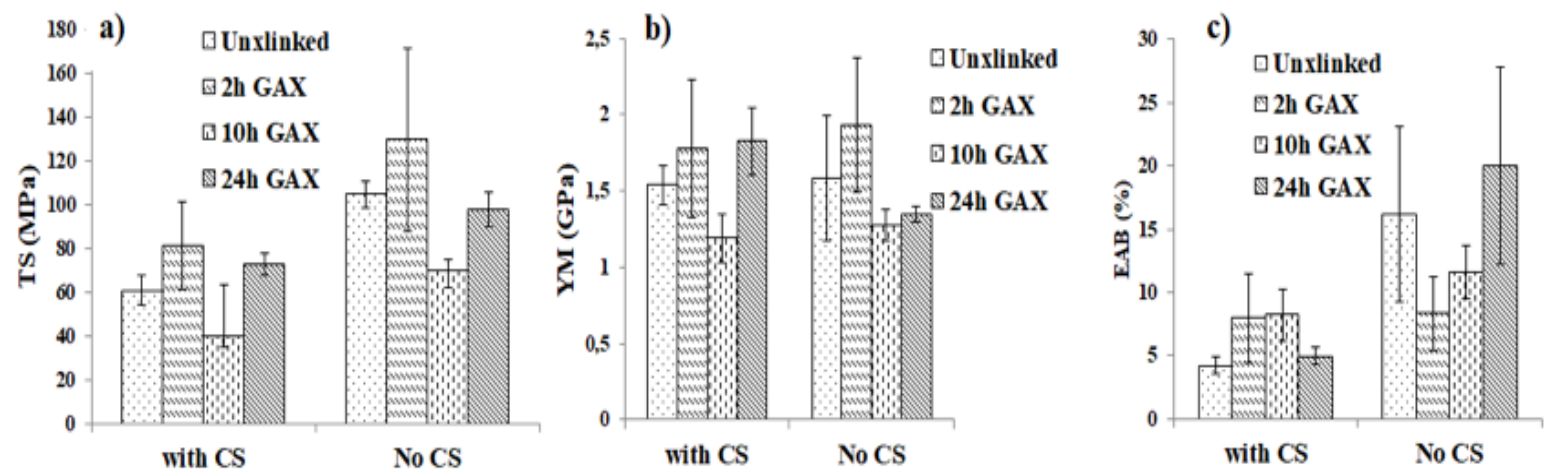

Figure 2. Mechanical test results of uncrosslinked and crosslinked $\mathrm{CHI}-\mathrm{GEL} / \mathrm{ALG}-\mathrm{CS} / \mathrm{CHI}-\mathrm{GEL}$ and $\mathrm{CHI}-\mathrm{GEL} / \mathrm{ALG} / \mathrm{CHI}-\mathrm{GEL}$ films. a) TS (MPa), b) YM (GPa), c) EAB (\%). 
in the average TS, YM and EAB\% values of the films with drug loading, down to $60.55 \pm 6.86 \mathrm{MPa}, 1.54 \pm$ $0.13 \mathrm{GPa}$ and $4.20 \pm 0.68 \%$, respectively. Similar trend was observed for all crosslinked films.

\section{Antibiotic release profiles}

For release studies, uncrosslinked and $24 \mathrm{~h}$ crosslinked samples having $1 \mathrm{mg}$ of CS, were tested at different $\mathrm{pH}$ conditions at $37 \mathrm{oC}$ and cumulative release versus time graphs were plotted. For all samples, high amount of release was observed within a few hours. The results obtained for CHI/ALG-CS/ $\mathrm{CHI}$ films are given in Table 2 and Figure 3. Release profiles of CS from gelatin containing CHI-GEL/ALG-

Table 2. Amount of $\mathrm{CS}$ released at various $\mathrm{pH}$ conditions from $\mathrm{CHI} / \mathrm{ALG}-\mathrm{CS} / \mathrm{CHI}$ films

\begin{tabular}{cccc}
\hline \multicolumn{2}{c}{ CHI/ALG-CS/CHI, uncrosslinked } & \multicolumn{2}{c}{ CHI/ALG-CS/CHI, crosslinked (24h) } \\
\hline $\begin{array}{c}\text { CS released } \\
\text { the end of } 24 \mathrm{~h})\end{array}$ & $\mathrm{pH}$ & $\begin{array}{c}\text { CS released } \\
\text { (at the end of } 24 \mathrm{~h} \text { ) }\end{array}$ & $\mathrm{pH}$ \\
\hline $40 \mu \mathrm{g} \pm 1$ & 5.5 & $35 \mu \mathrm{g} \pm 2$ & 5.5 \\
$31 \mu \mathrm{g} \pm 2$ & 7.4 & $28 \mu \mathrm{g} \pm 4$ & 7.4 \\
$23 \mu \mathrm{g} \pm 4$ & 10.0 & $23 \mu \mathrm{g} \pm 2$ & 10.0 \\
\hline
\end{tabular}
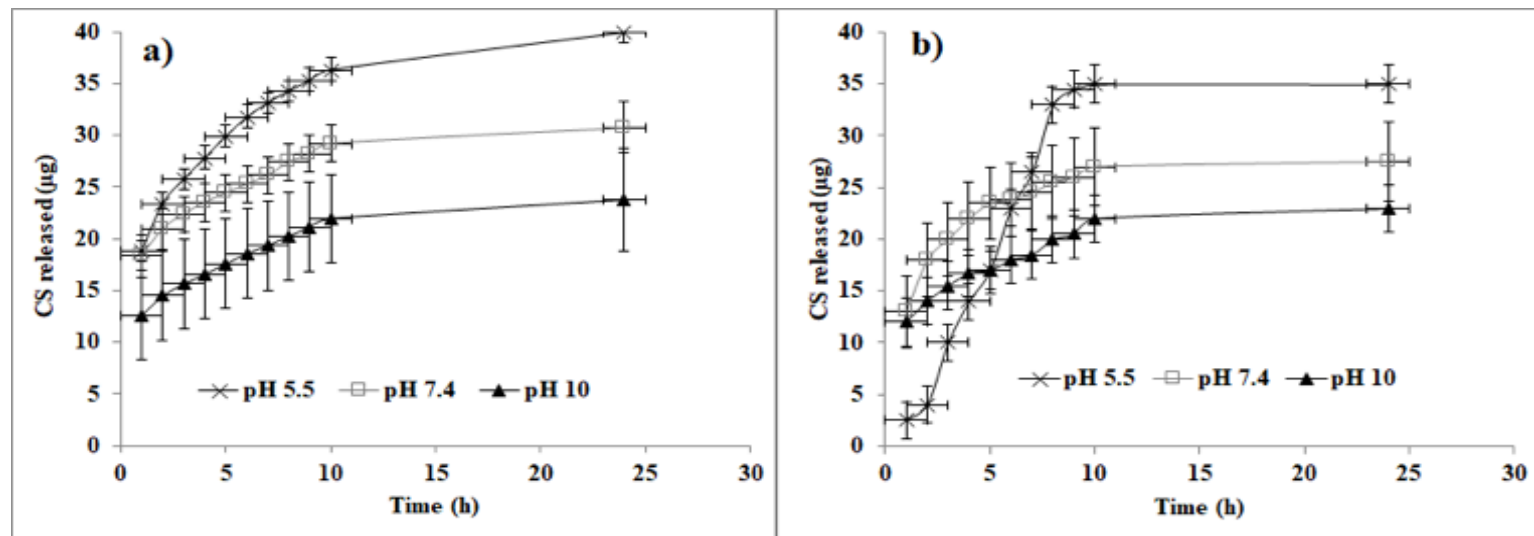

Figure 3. Amount of CS released in various pH conditions from a) uncrosslinked, b) 24h crosslinked CHI/ALG-CS/CHI films.

Table 3. Amount of CS released at various $\mathrm{pH}$ conditions from CHI-GEL/ALG-CS/CHI-GEL films

CHI-GEL/ALG-CS/CHI-GEL, uncrosslinked

\begin{tabular}{cccc}
\hline $\begin{array}{c}\text { CS released } \\
\text { (at the end of } 24 \mathrm{~h} \text { ) }\end{array}$ & $\mathrm{pH}$ & $\begin{array}{c}\text { CS released } \\
\text { (at the end of } 24 \mathrm{~h} \text { ) }\end{array}$ & $\mathrm{pH}$ \\
\hline $887 \mu \mathrm{g} \pm 80$ & 5.5 & $43 \mu \mathrm{g} \pm 1$ & 5.5 \\
$482 \mu \mathrm{g} \pm 65$ & 7.4 & $48 \mu \mathrm{g} \pm 2$ & 7.4 \\
$70 \mu \mathrm{g} \pm 15$ & 10.0 & $80 \mu \mathrm{g} \pm 3$ & 10.0 \\
\hline
\end{tabular}



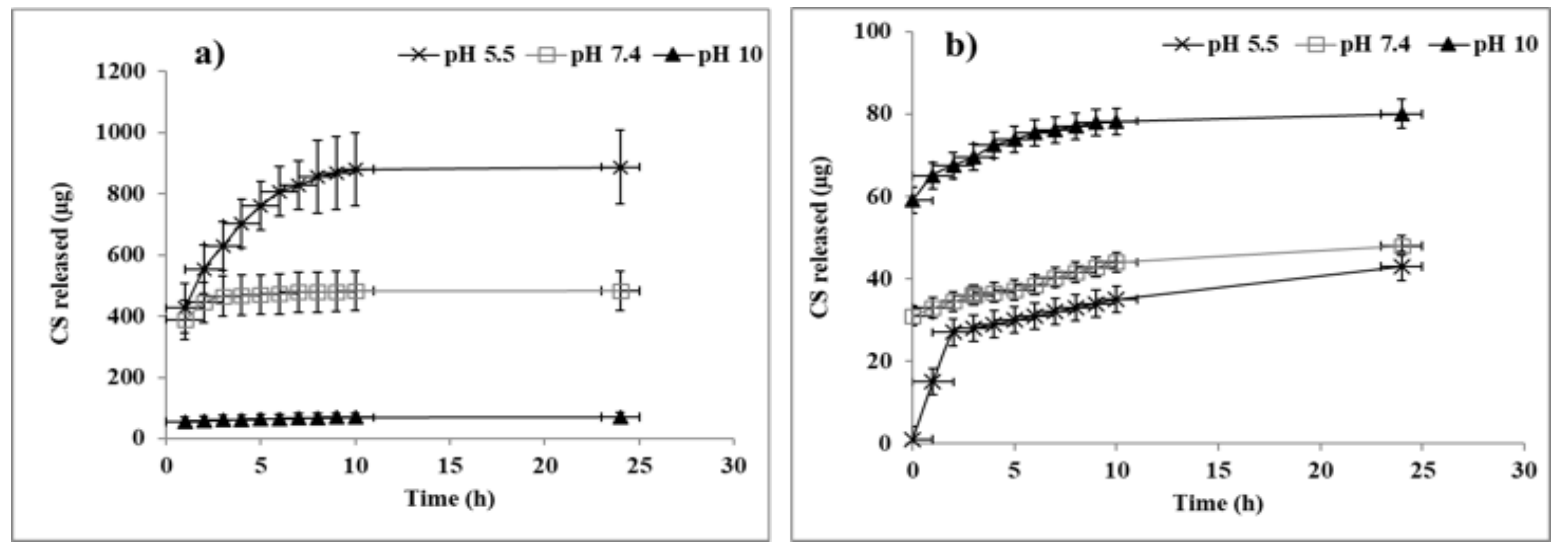

Figure 4. Amount of CS released in various $\mathrm{pH}$ conditions from a) uncrosslinked, b) $24 \mathrm{~h}$ crosslinked CHI-GEL/ALG-CS/CHIGEL films

$\mathrm{CS} / \mathrm{CHI}$-GEL samples in both cases as crosslinked and uncrosslinked forms are given in Table 3 and Figure 4 .

\section{Antibacterial tests}

Agar spot test was used to investigate the antibacterial effects of released CS from the crosslinked films. For the analysis, pH 5.5 PBS solutions including the released CS from the CHI-GEL/ALG-CS/CHI-GEL films crosslinked with either $2 \mathrm{~h}$ or $24 \mathrm{~h}$ GA treatment were used. Solutions containing the released CS were placed on agar plates. As control groups, PBS solutions (pH 5.5) gathered from the drug free films, namely $\mathrm{CHI}$ GEL/ALG/CHI-GEL films. Inhibition zones obtained for $2 \mathrm{~h}$ GA crosslinked and $24 \mathrm{~h}$ GA crosslinked samples are given in Figure $5 \mathrm{a}$ and Figure $5 \mathrm{~b}$, and the controls for $2 \mathrm{~h}$ and $24 \mathrm{~h}$ crosslinked films without drug loading are given in Figure $5 c$ and Figure $5 d$, respectively. Figure $5 e$ represents the drug solution itself as a positive control.

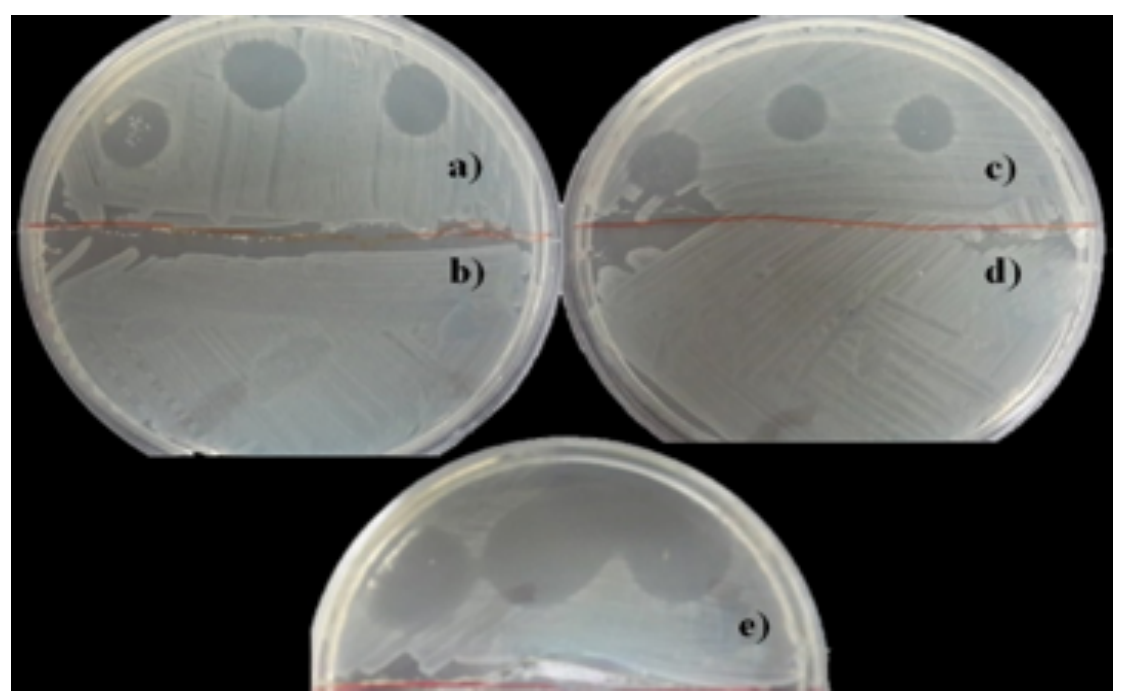

Figure 5. Photograph of $E$. coli spread agar plate after incubation at $37^{\circ} \mathrm{C}$ for $24 \mathrm{~h}$; (a) $2 \mathrm{~h}$ GA treated CHI-GEL/ALG-CS/ CHI-GEL, (b) Control: 2 h GA treated CHI-GEL/ALG/CHI-GEL, (c) 10 h GAtreated CHI-GEL/ALG-CS/CHI-GEL, (d) Control: 10 $\mathrm{h}$ GAX CHI-GEL/ALG / CHI-GEL and (e) CS dissolved in distilled water (b and d are represents drug free control films treated in the same way as the drug loaded films) 


\section{DISCUSSION}

In this study, mechanical properties of the multilayer films and drug containing ones, both in their uncrosslinked and crosslinked forms, were characterized. Addition of GEL to the first and the third layers increased the tensile strength of the films from $88.60 \pm 7.86 \mathrm{MPa}$ to $104.52 \pm 5.90 \mathrm{MPa}$. Meanwhile, tensile strength of the films did not demonstrate a linear increase with the increase in crosslinking duration. Especially $2 \mathrm{~h}$ and $10 \mathrm{~h}$ crosslinked samples demonstrated large deviations in TS values. This might be a result of insufficient crosslinking time, causing inhomogeneous distribution of chemical bonds within the membrane structure. In literature, it was mentioned that crosslinking of films by immersion method might produce more homogenous structures than by vapor phase treatment method (29). Bigi et al. reported that the level of crosslinking was influenced by the wetness of the films. Effect of GA on wet gelatin films was greater than that of on dry films which explained by the fact crosslinking reduces the amount of water associated with the gelatin protein in wet conditions (30). On the other hand, incorporation of the drug decreased the mechanical properties of the films. Several studies reported changes in mechanical properties for the polymeric structures after loading with small molecule drugs. This was explained due to drug-polymer interactions. In a previous study, a significant decrease in elastic modulus was reported for PLA/PEG fibers loaded with $10 \%$ of 5-nitro-8hydroxyquinoline, an antibacterial drug (31). Chou et al. showed that tensile strength and young modulus of PCL/PLGA electrospun meshes were not significantly affected by loading tenofovir (a small hydrophilic drug) up to $40 \%(\mathrm{w} / \mathrm{w})$ (32). Literature findings suggest that drug-polymer interactions become more significant at higher loading concentrations in the sense of mechanical properties. Most probably, presence of the drug affected and disturbed the organization of polymeric chains and resulted with decrease in mechanical strength. Our results are in agreement with the literature, since our drug loading concentration was around 48\% (w/w).
The antibiotic drug ceftriaxone sodium (CS), is a third generation cephalosporin used in the management of mild to moderate infections caused due to susceptible microorganism (33). The alginate was chosen as a drug carrier in our multilayer system since it has been conventionally used in drug products as a thickening, gel forming and stabilizing agent (18). The rapid release of CS can be attributed to hydrophilic structures of the films and the high solubility of CS in aqueous media (34). Comparing the drug release from crosslinked and uncrosslinked films (Figure $3 a$ ) and Figure $3 \mathrm{~b})$ ), it was expected that crosslinking would lessen the release of the drug. However, the results show that the release was not significantly affected by crosslinking. After $24 \mathrm{~h}$, the total amounts of released CS from uncrosslinked and crosslinked films were $40 \pm$ $1 \mu \mathrm{g}$ and $35 \pm 2 \mu \mathrm{g}$, respectively. This may be explained as; the interaction between the amine groups of $\mathrm{CHI}$ and carboxyl groups of both alginate and CS seems to prevent and retard the release of CS from the films after crosslinking. The drug release was higher in acidic conditions at $\mathrm{pH}$ 5.5. At low $\mathrm{pH}$ values, most of the carboxyl groups of alginate and amine units of chitosan are protonated leading to weak interaction between alginate and chitosan, thus favoring the drug release. In a previous study, molecular interaction of ceftriaxone sodium and alginic acid was investigated in a bead formulation prepared by ionotropic-external gelation technique by using calcium chloride as a crosslinking agent. FT-IR spectrum of formulated beads, indicated the absence of chemical interactions between the drug and the polymers (35). On the other hand, the effect of the interaction between chitosan and alginate on drug release at different $\mathrm{pH}$ values has been shown in several studies (36). Pasparakis et al. compared the release of antihypertensive drug verapamil from calcium-alginate and calcium alginatechitosan beads and observed that the presence of chitosan significantly retarded the release of the drug from the beads and this was attributed to the polyelectrolyte complex formation between these two polymers. They also reported shrinkage of the beads in acidic media and this enhanced the diffusion of the drug molecules from the beads. 
On the other hand, a significant difference was observed in the release profiles of CS from gelatin containing films. Total amount of CS released in $24 \mathrm{~h}$ in medium having $\mathrm{pH} 5.5$ was $887 \pm 80 \mu \mathrm{g}$ and $43 \pm$ $1 \mu \mathrm{g}$ from uncrosslinked (Figure 4a) and crosslinked samples (Figure 4b), respectively. The high amount of release from uncrosslinked samples may be attributed to the high solubility of the GEL, dissolution of which enhanced the drug release parallel to its dissolution.

The release of CS also showed significant difference in various $\mathrm{pH}$ conditions for the uncrosslinked GEL containing samples. CS was released most readily and fast in acidic media in which pH 5.5, and almost all loaded CS was released in $24 \mathrm{~h}$. Meanwhile, the release from the samples crosslinked with $24 \mathrm{~h}$ GA treatment demonstrated reverse trend compared to the results found for $\mathrm{CHI} / \mathrm{ALG}-\mathrm{CS} / \mathrm{CHI}$ samples. This can be explained by the presence of crosslinked GEL, preventing $\mathrm{CHI}$ and $\mathrm{CS}$ bonding by stabilizing the film, making it stronger and holding the multilayers of the film together. Mechanical test results also support this finding. Release solutions belonging to CS loaded films showed antibacterial efficacy and retained this property upon $2 \mathrm{~h}$ GA crosslinked and $24 \mathrm{~h}$ GA crosslinked samples.

\section{CONCLUSION}

In this study, 3-layer films having micrometer thicknesses were prepared by using biocompatible and biodegradable chitosan, gelatin and alginate and their mechanical properties and drug release profiles were investigated. The films were functionalized through incorporation of an antibiotic, ceftriaxone sodium (CS), which is used as a model bioactive agent. The results indicate that physical entrapment of the drug was enhanced by the polyelectrolyte complex between the chitosan and alginate and the presence of gelatin favored the mechanical strength of the films. Release profiles show the potential capability of the films to be used for medical applications.

\section{ACKNOWLEDGMENT}

Authors are grateful to METU and METU-BIOMATEN Center of Excellence in Biomaterials and Tissue Engineering for supporting the research. Antibacterial tests were conducted at METU Health Center.

\section{REFERENCES}

1. Song Z, Xu Y, Yang W, Cui L, Zhang J, Liu J. Graphene/ tri-block copolymer composites prepared via RAFT polymerizations for dual controlled drug delivery via $\mathrm{pH}$ stimulation and biodegradation. Eur Polym J, 2015; 69: 559-72.

2. Mohanty $S$, Alm $M$, Hemmingsen $M$, DolatshahiPirouz A, Trifol J, Thomsen P, et al. 3D Printed Silicone-Hydrogel Scaffold with Enhanced Physicochemical Properties. Biomacromolecules, 2016, 17(4): 1321-9.

3. Kim J, Hwang J, Seo Y, Jo Y, Son J, Paik T, et al. Engineered self-expander hydrogel for sustained release of drug molecules. J Ind Eng Chem, 2016, 42: $121-5$.

4. Dogan S, Demirer S, Kepenekci I, Erkek B, Kiziltay $A$, Hasirci N. et al. Epidermal growth factorcontaining wound closure enhances wound healing in non-diabetic and diabetic rats. Int Wound $\mathrm{J}$, 2009, 6: 107-15.
5. Ulubayram, K, Kiziltay A, Yilmaz E, Hasirci N. Desferrioxamine release from gelatin based sytems. Biotechnol Appl Bioc, 2005, 42: 237-45.

6. Eke G, Mangir N, Hasirci N, MacNeil S, Hasirci V. Development of a UV crosslinked biodegradable hydrogel containing adipose derived stem cells to promote vascularization for skin wounds and tissue engineering. Biomaterials, 2017, 129: 188-98.

7. İmamoğlu Ö. Biyokontrolde Doğal Ürünlerin Kullanılması, Kitosan. Turk Hij Den Biyol Derg, 2011, 68(4): 215-22.

8. Baghaie, S; Khorasani, M.T; Zarrabi, A; Moshtaghian, J. Wound healing properties of PVA/starch/chitosan hydrogel membranes with nano Zinc oxide as antibacterial wound dressing material. J Biomater Sci Polym Ed, 2017, 28: 2220-41.

9. Dursun Usal T, Yucel D, Hasirci V. A novel GelMA-pHEMA hydrogel nerve guide for the treatment of peripheral nerve damages. Int J Biol Macromol, 2019, 121: 699-706. 
10. Reis RL, Neves NM, Mano JF, Gomes ME, Marques AP, Azevedo HS. Natural-Based Polymers for Biomedical Applications. Woodhead Publishing: Cambridge, England 2008.

11. Tchobanian A, Oosterwyck HV, Fardim P. Polysaccharides for tissue engineering: Current landscape and future prospects. Carbohyd Polym, 2019, 205: 601-25.

12. Ucar S, Ermis M, Hasirci N. Modified chitosan scaffolds: Proliferative, cytotoxic, apoptotic and necrotic effects on Saos- 2 cells and antimicrobial effect on E.coli. J Bioact Compat Pol, 2016, 31: 304-19.

13. Kara F, Aksoy EA, Calamak S, Hasirci N, Aksoy S. Immobilization of heparin on chitosan grafted polyurethane films to enhance its anti-adhesive and antibacterial properties against bacteria. J Bioact Compat Pol, 2016, 31: 72-90.

14. Endogan T, Kiziltay A, Kose GT, Comunoglu N, Beyzadeoglu T, Hasirci N. Acrylic bone cements: Effects of the poly(methyl methacrylate) powder size and chitosan addition on their properties. J Appl Polym Sci, 2014,131: doi: 10.1002/app.39662.

15. Balun Kayan D, Polat V. Improvement of electrochemical and structural properties of polycarbazole by simultaneous electrodeposition of chitosan. Turk J Chem, 2017, 41: 233-42.

16. Isikli C, Hasirci V, Hasirci N. Development of Porous Chitosan-Gelatin/Hydroxyapatite Composite Scaffolds for Hard Tissue Engineering Applications. J Tissue Eng Regen Med, 2012, 6: 135-43.

17. Sionkowska A, Kaczmarek B, Gadzala-Kopciuch R. Gentamicin release from chitosan and collagen composites. J Drug Deliv Sci Technol, 2016, 35: 353-359.

18. Tønnesen $\mathrm{HH}$, Karlsen J. Alginate in drug delivery systems. Drug Dev Ind Pharm, 2002, 28(6): 621-30

19. Lee H, Woo HM, Kang BJ. Impact of collagenalginate composition from microbead morphological properties to microencapsulated canine adipose tissue-derived mesenchymal stem cell activities. J Biomater Sci Polym Ed, 2017, 6: 1-11.

20. Finotelli PV, Da Silva D, Sola-Penna M, M Rossi A, Farina M, Andrade LR. Et al. Microcapsules of alginate/chitosan containing magnetic nanoparticles for controlled release of insulin. Colloids and Surfaces B, 2010, 81: 206-11.

21. Tigli RS, Gumusderelioglu M. Evaluation of alginatechitosan semi IPNs as cartilage scaffolds. J Mater Sci Mater Med, 2009, 20: 699-709.

22. Hritcu D, Popa MI, Popa N, Badescu V, Balan V. Preparation and characterization of magnetic chitosan nanospheres. Turk J Chem, 2009, 33: 785-96.

23. Hammond PT. Building biomedical materials layerby-layer. Mater Today, 2012, 15: 196-206.
24. Silva D, Pinto LFV, Bozukova D, Santos LF, Serro A P, Saramago B. Chitosan/alginate based multilayers to control drug release from ophthalmic lens. Colloids Surf B Biointerfaces, 2016, 147: 81-89.

25. Zhang YZ, Venugopal J, Huang ZM, Lim C, Ramakrishna S. Crosslinking of the electrospun gelatin nanofibers. Polymer, 2006, 47: 2911-17.

26. Isikli $C$, and Hasirci N. Surface and cell affinity properties of chitosan-gelatin-hydroxyapatite composite films. Key Eng Mater, 2012, 493-494: 337-342.

27. Bouryabaf LS, Moradi M, Tajik H. Badali A. Biofilm Removal and Antimicrobial Activities of Agar Hydrogel Containing Salmonella typhimurium. J Med Bacteriol, 2017, 6: 51-58.

28. Silva MA, Krause Bierhalz AC, Kieckbusch TG. Alginate and pectin composite films crosslinked with Ca2+ ions: Effect of the plasticizer concentration. Carbohydr Polym, 2009, 77: 736-42.

29. Chou SF, Luo LJ, Lai JY, Kang Ma DH. Role of solventmediated carbodiimide cross-linking in fabrication of electrospun gelatin nanofibrous membranes as ophthalmic biomaterials. Mater Sci Eng C, 2017, 71: 1145-55.

30. Bigi A, Cojazzi G, Panzavolta S, Rubinia K, Roveri N. Mechanical and thermal properties of gelatin films at different degrees of glutaraldehyde crosslinking. Biomaterials, 2001, 22: 763-68.

31. Toncheva A, Mincheva R, Kancheva M, Manolova N, Rashkov I, Dubois P, Markova N. Antibacterial PLA/PEG electrospun fibers: Comparative study between grafting and blending PEG. Eur Polym J, 2016, 75: 223-33.

32. Chou SF, Woodrow KA. Relationships between mechanical properties and drug release from electrospun fibers of PCL and PLGA blends. J Mech Behav Biomed Mater, 2017, 65: 724-33.

33. M. Owens H, K. Dash A. Ceftriaxone Sodium: Comprehensive Profile. Profiles Drug Subst Excip Relat Methodol, 2003, 30: 21-57.

34. Ofokansi KC, Adikwu MU, Okore VC. Preparation and Evaluation of Mucin-Gelatin Mucoadhesive Microspheres for Rectal Delivery of Ceftriaxone Sodium. Drug Dev Ind Pharm, 2007, 33: 691-700.

35. Lalwani D. An oral dosage form of ceftriaxone sodium using enteric coated sustained release calcium alginate beads. MS, the Department of Pharmaceutical Sciences, The University of Toledo, 2015.

36. Pasparakis G, Bouropoulos N. Swelling studies and in vitro release of verapamil from calcium alginate and calcium alginate-chitosan beads. Int J Pharm, 2006, 323: 34-42. 